\title{
Simulasi Homogenitas Pencampuran Air Limbah Pabrik Kelapa Sawit dan Pengaruhnya Terhadap Pengolahan Awal di Kolam Ekualisasi Pilot Plant Biogas Sei Pagar
}

\section{Mixing Homogeneity Simulation of Palm Oil Mill Effluent and Its Effect of Equalization Tank Preatreatment in Sei Pagar Biogas Pilot Plant}

\author{
IMRON MASFURI, SOLEH, ASTRI PERTIWI, BAMBANG MUHARTO, TRISAKSONO B. P. \\ Pusat Teknologi Pengembangan Sumberdaya Energi dan Industri Kimia (PTSEIK) BPPT \\ Gedung 625, Kawasan Puspiptek, Tangerang Selatan, telepon/fax. 021-75791355 \\ E-mail: imron.masfuri@bppt.go.id
}

\begin{abstract}
Palm oil mill effluent (POME) produced from palm oil mills is classified as waste that can pollute the environment and needs severe treatment because it still contains high BOD and COD. POME has the potential to be further processed to produce biogas products through the anaerobic digestion process. Anaerobic process of biogas production from Palm Oil Mill Effluent (POME) waste is a fermentation process which quite a long time. So it is necessary to have a POME pretreatment process for preparation before being fed into the biodigester reactor. It is aimed at considering optimum conditioning, good homogeneity, and preparing for the formation of gas products. One of the POME pretreatment steps was carried out in an equalization tank to be homogenized before entering the reactor. However, when passing the equalization process, there are indications of sedimentation or separation between liquid waste and dissolved solids. Thus, an attempt was made to carry out a stirring system so that homogeneity would occur with the agitator. Therefore, the POME conditions in all parts of the pond could be relatively similar. The stirring is one of the factors that influence microbial life. In this research, a stirrer design simulation will be conducted to determine the effectiveness of the stirrer and homogeneity of POME in equalization pond. Design is adjusted to the actual POME parameters according to results of the analysis carried out related to POME physical properties such as temperature, density, viscosity, $\mathrm{pH}$, and flow rate. Conditions analyzed in the simulation are agitator speed, the direction of fluid flow, power consumption, and homogeneity of mixing.
\end{abstract}

Keywords: agitator, mixing, equalization tank, homogeneity, POME

\begin{abstract}
ABSTRAK
Limbah cair pabrik kelapa sawit (POME) yang dihasilkan dari pabrik pengolahan sawit tergolong limbah yang dapat mencemari lingkungan dan perlu penanganan serius, karena masih mengandung $B O D$ dan $C O D$ tinggi. POME sangat berpotensi untuk diolah lebih lanjut untuk menghasilkan produk biogas melalui proses penguraian anaerob. Proses pengolahan air limbah pabrik minyak sawit menjadi biogas merupakan proses fermentasi anaerobik yang memerlukan waktu yang lama. Oleh karena itu, perlu adanya proses pengolahan awal POME untuk penyiapan sebelum diumpankan ke dalam reaktor biodigester untuk pengkondisian yang optimum, homogenitas yang baik, dan persiapan pembentukan produk gas. Salah satu pengolahan awal POME dilakukan di kolam ekualisasi untuk proses homogenisasi air limbah sebelum masuk ke dalam reaktor. Selama melewati kolam ekualisasi, ada indikasi terjadi pengendapan atau pemisahan antara limbah cair dengan padatan terlarut. Untuk itu, muncul upaya untuk melakukan sistem pengadukan agar tercapai kondisi homogen dengan menggunakan pengaduk agar kondisi POME di seluruh bagian kolam relatif sama. Adapun pengadukan merupakan salah satu faktor yang berpengaruh pada kehidupan mikroba. Pada penelitian ini akan dilakukan simulasi desain pengaduk yang untuk mengetahui efektivitas pengaduk dan homogenitas POME di dalam kolam equalisasi. Desain disesuaikan dengan parameter POME sesuai hasil analisis yang dilakukan terkait properti fisik POME seperti temperatur, densitas, viskositas, $\mathrm{pH}$, dan laju alir. Kondisi yang dianalisis dalam simulasi adalah kecepatan putaran pengaduk, arah aliran fluida, konsumsi daya dan homogenitas pencampuran.
\end{abstract}

Kata kunci: pengaduk, pencampuran, kolam ekualisasi, homogenitas, POME 


\section{PENDAHULUAN}

Pabrik pengolahan kelapa sawit menghasilkan tiga jenis limbah yaitu limbah padat, cair dan gas ${ }^{(1)}$. Limbah cair pabrik kelapa sawit merupakan limbah yang paling banyak dihasilkan dari tandan segar buah kelapa sawit. Satu tandan buah segar kelapa sawit mengandung sekitar $60 \%$ limbah cair sawit yang lebih dikenal dengan nama POME (Palm Oil Mill Effluent)(2). POME adalah salah satu limbah utama industri kelapa sawit yang memiliki potensi pencemaran lingkungan yang paling bermasalah di antara limbah pabrik lainnya. Limbah POME buangan dari pabrik kelapa sawit dapat mencemari sungai dan tanah di sekitarnya karena memiliki $\mathrm{pH}$ rendah, kandungan minyak dan lemak serta bahan pencemar lainnya yang tinggi $(3,4)$.

Pengolahan POME menjadi biogas akan diterapkan di Pabrik Kelapa Sawit (PKS) Sei Pagar dengan sistem pengolahan awal menggunakan kolam ekualisasi untuk mempersiapkan POME untuk diumpankan ke dalam reaktor. Kolam ekualisasi yang telah dibangun di lokasi plant biogas berukuran panjang lebar dan tingginya 7,0 x 7,0 x 3,0 meter, yang akan dilengkapi dengan sistem pengadukan berupa satu buah pengaduk yang ditempatkan pada tengah kolam ekualisasi.

Pada penelitian ini dilakukan evaluasi desain dan simulasi prototipe sistem pengaduk (agitator) yang akan diterapkan pada kolam ekualisasi POME untuk mengetahui proses agitasi dan homogenisasi, serta pengaruh terhadap proses pretreatment POME untuk produksi biogas.

\section{BAHAN DAN METODE}

\subsection{Lokasi Penelitian}

Penelitian ini dilakukan di pilot plant produksi biogas POME yang berlokasi di PKS Sei Pagar milik PTPN V, Hang Tuah, Perhentian Raja, Kabupaten Kampar, Provinsi Riau. Penelitian ini difokuskan pada area pengolahan POME di bagian kolam ekualisasi berpengaduk.

\subsection{Jenis Fluida}

Jenis fluida yang digunakan dalam simulasi ini adalah limbah cair pabrik kelapa sawit yang berasal dari Pabrik Kelapa Sawit Sei Pagar, PTPN V Riau. Karakteristik POME berdasarkan hasil analisis yang telah dilakukan pada sampling POME di kolam fatpit seperti ditunjukkan pada Tabel 1.

\subsection{Perangkat Lunak untuk Simulasi}

Simulasi proses homogenitas pengadukan yang terjadi di dalam kolam ekualisasi menggunakan perangkat lunak ANSYS Fluent ${ }^{(5)}$. Perangkat lunak ini mampu memvisualisasikan sistem agitasi di kolam ekualisasi secara CFD (Computational Fluid Dynamics) yang nantinya akan diterapkan pada sistem pretreatment POME di plant produksi biogas PKS Sei Pagar.

CFD merupakan analisa sistem yang melibatkan aliran fluida, perpindahan massa dan panas, serta fenomena yang terkait lainnya seperti pencampuran, reaksi kimia dengan menggunakan simulasi komputer ${ }^{(6,7)}$. Dalam penelitian ini, CFD digunakan untuk mengevaluasi dan memvisualisasi pergerakan fluida dari desain pengaduk yang akan diterapkan di kolam ekualisasi untuk pretreatment POME. Metode ini meliputi fenomena yang berhubungan dengan aliran fluida, fenomena pencampuran, kecepatan putaran pengaduk, dan waktu pencapaian homogenitas POME.

Tabel 1. Parameter limbah POME

\begin{tabular}{clc}
\hline No. & Parameter & Nilai \\
\hline 1 & Densitas & $950-980 \mathrm{~kg} / \mathrm{m}^{3}$ \\
\hline 2 & Viskositas & $2-10 \mathrm{cP}$ \\
\hline 3 & Temperatur & $60-70{ }^{\circ} \mathrm{C}$ \\
\hline 3 & Laju Alir & $10 \mathrm{~m}^{3} / \mathrm{jam}$ \\
\hline 4 & pH & $4,0-4,5$ \\
\hline 5 & TSS & $4.500 \mathrm{mg} / \mathrm{L}$ \\
\hline 6 & BOD & $3.000 \mathrm{mg} / \mathrm{L}$ \\
\hline 7 & COD & $70.000 \mathrm{mg} / \mathrm{L}$ \\
\hline
\end{tabular}

\subsection{Perangkat Lunak untuk Simulasi}

Simulasi proses homogenitas pengadukan yang terjadi di dalam kolam ekualisasi menggunakan perangkat lunak ANSYS Fluent ${ }^{(5)}$. Perangkat lunak ini mampu memvisualisasikan sistem agitasi di kolam ekualisasi secara CFD yang nantinya akan diterapkan pada sistem pretreatment POME di plant produksi biogas PKS Sei Pagar.

CFD merupakan analisa sistem yang melibatkan aliran fluida, perpindahan massa dan panas, serta fenomena yang terkait lainnya seperti pencampuran, reaksi kimia dengan menggunakan simulasi komputer ${ }^{(6,7)}$. Dalam penelitian ini, CFD digunakan untuk mengevaluasi dan memvisualisasi pergerakan fluida dari desain pengaduk yang akan diterapkan di kolam ekualisasi untuk pretreatment POME. Metode ini meliputi fenomena yang berhubungan dengan aliran fluida, fenomena pencampuran, kecepatan putaran pengaduk, dan waktu pencapaian homogenitas POME.

\subsection{Desain Pengaduk}

Berdasarkan gambar desain pengaduk yang telah ada sebelumnya, diketahui dimensi dan tipe pengaduk yang akan digunakan pada kolam ekualisasi POME adalah sebagai berikut : 
a. Kolam Ekualisasi

Kolam ekualisasi berbentuk alas persegi datar berukuran $7 \times 7$ meter dengan tinggi 3 meter. Alas dan dinding kolam terbuat dari material beton dengan ketebalan $25 \mathrm{~cm}$. Kolam didesain untuk pretreatment POME dengan kapasitas $85 \%$ dari total volume fluida, atau sekitar $125 \mathrm{~m}^{3}$.

b. Pengaduk (Agitator)

Pengaduk pada kolam ekualisasi berfungsi sebagai unit pengaduk untuk homogenisasi POME yang ada di dalam kolam. Tipe impeller yang digunakan adalah pitch blade turbine dengan jumlah blade 4 buah yang dipasang dengan kemiringan blade $45^{\circ}(8)$. Pengaduk akan diposisikan pada bagian tengah kolam ekualisasi yang ditunjang oleh 4 buah pilar penyangga beton. Dimensi pengaduk ditunjukkan pada Gambar 1.

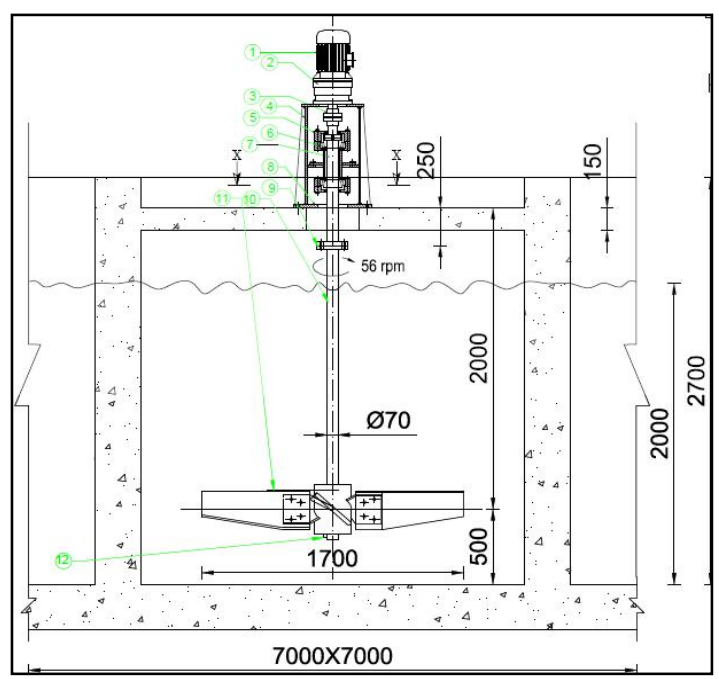

Gambar 1. Desain pengaduk pada kolam ekualisasi

Dimensi pengaduk yang telah dirancang mempunyai ukuran dan spesifikasi sesuai pada Tabel 2.

Tabel 2. Spesifikasi pengaduk pada kolam ekualisasi

\begin{tabular}{|c|c|}
\hline - Tipe blade & Pitch blade turbine \\
\hline - Diameter blade & $1,70 \mathrm{~m}$ \\
\hline - Jumlah blade & 4 buah \\
\hline - Angle blade & $45^{\circ}$ \\
\hline - Diameter shaft & $70 \mathrm{~mm}$ \\
\hline - Panjang shaft & $2,0 \mathrm{~m}$ \\
\hline - Jarak dari dasar & $50 \mathrm{~cm}$ \\
\hline
\end{tabular}

\section{HASIL DAN PEMBAHASAN}

\subsection{Evaluasi Desain Pengaduk}

Evaluasi desain pengaduk meliputi pengecekan pemilihan spesifikasi dan ukuran tiap bagian alat pengaduk.
- Perhitungan volume efektif

Kolam ekualisasi hanya terisi POME maksimal $85 \%$ dari total kapasitas penuh ${ }^{(9)}$.

$$
\begin{aligned}
\mathrm{V}_{\text {ef }} & =\text { A.h. } 85 \% \\
& =7 \times 7 \times 3 \times 85 \% \\
& =124,95 \mathrm{~m}^{3}
\end{aligned}
$$

- Penentuan ukuran panjang blade

Pada tipe impeller pitch blade, dipilih rasio $\mathrm{D} / \mathrm{T}=0,3^{(9)}$. Dimana $\mathrm{D}$ adalah panjang atau diameter impeller dan $\mathrm{T}$ adalah panjang atau diameter kolam. Diketahui bahwa panjang sisi kolam ekualisasi adalah 7 meter, maka panjang efektif blade adalah:

$$
\begin{aligned}
\mathrm{D} & =0,3 \times \mathrm{T} \\
& =0,3 \times 7 \\
& =2,1 \text { meter }
\end{aligned}
$$

- Perhitungan nilai Reynold Number

Penentuan Reynold Number berdasarkan pada rumus $1^{(10,11)}$ :

$$
\text { Nre }=\frac{\rho_{f} \cdot N \cdot D_{a}}{\mu_{f}}
$$

Fluida yang digunakan adalah limbah POME dengan density $\left(\rho_{\mathrm{f}}\right)=980 \mathrm{~kg} / \mathrm{m}^{3}$, viscosity $\left(\mu_{\mathrm{f}}\right)$ $=3,82 \mathrm{cP}$ dan putaran $(\mathrm{N})=50 \mathrm{rpm}$. Maka diperoleh nilai Reynold $\left(\mathrm{N}_{\mathrm{Re}}\right)=26.923$.

- Penentuan power number

Berdasarkan grafik power number untuk impeller pitch blade turbine dengan $\mathrm{N}_{\mathrm{Re}} \mathrm{di}$ atas, maka dipilih $\mathrm{Np}=1,3^{(11)}$. Grafik kurva power number ditunjukkan pada Gambar 2.

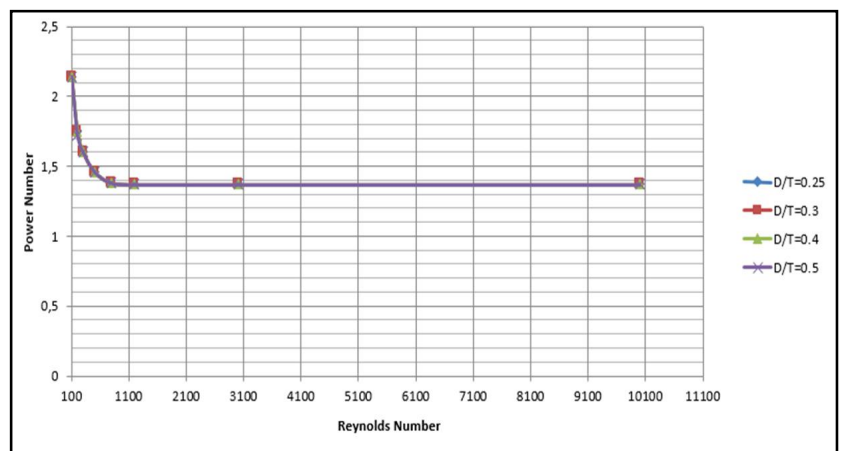

Gambar 2. Kurva power number ${ }^{(11)}$

- Perhitungan kebutuhan daya Kebutuhan daya dihitung dengan menggunakan rumus $2^{(11)}$ :

$$
P=\frac{N_{p} \cdot N^{3} \cdot D^{5} \cdot \rho_{f}}{g_{c}}
$$

$\mathrm{Np} \quad=$ Power Number $\left(\mathrm{kg} \mathrm{m}^{2} / \mathrm{s}^{2}\right)$

$\mathrm{P} \quad=$ Power (watt)

$g_{c} \quad=$ Konstanta grafitasi $\left(1 \mathrm{kgm} / \mathrm{Ns}^{2}\right)$

$\mathrm{N} \quad=$ Kecepatan pengadukan (rps)

$\rho_{f} \quad=$ Densitas fluida $\left(\mathrm{kg} / \mathrm{m}^{3}\right)$

$\mathrm{D}=$ Diameter pengaduk $(\mathrm{m})$ 
Dengan asumsi beban maksimum $80 \%$ dari total daya, maka daya yang dibutuhkan dapat dihitung sebagai berikut :

$P=\left(1,3 \cdot(56 / 60)^{3} \times(1,7)^{5} \times 985 / 1\right) / 80 \%$

$P=14.782,04 / 80 \%=18.477,56$ watt

$\mathrm{P}=24,77 \mathrm{HP}$

\subsection{Hasil Simulasi CFD}

Simulasi CFD yang dihasilkan menggunakan ANSYS Fluent meliputi profil aliran fluida, kecepatan putaran, dan waktu untuk mencapai homogenitas pengadukan fluida di dalam kolam ekualisasi. Berdasarkan data simulasi menunjukkan hasil sebagai berikut :

\section{Skema Simulasi}

Kolam berukuran $7 \times 7 \times 3$ meter berisikan cairan limbah dengan viskositas $7,5 \mathrm{cP}$ dan densitas $985 \mathrm{~kg} / \mathrm{m}^{3}$ diaduk dengan menggunakan pengaduk. Impeller terdiri dari 4 buah blade berputar dengan kecepatan pengadukan $56 \mathrm{rpm}$ dengan tinggi ruang kosong dikondisikan 20\% dari total tinggi kolam. Tujuan simulasi ini adalah untuk mengetahui karakteristik keseragaman dan sirkulasi aliran limbah di dalam kolam. Simulasi dilakukan hingga tercapai kondisi pengadukan dan resirkulasi aliran yang merata. Geometri simulasi kolam ekualisasi ditunjukkan pada Gambar 3.

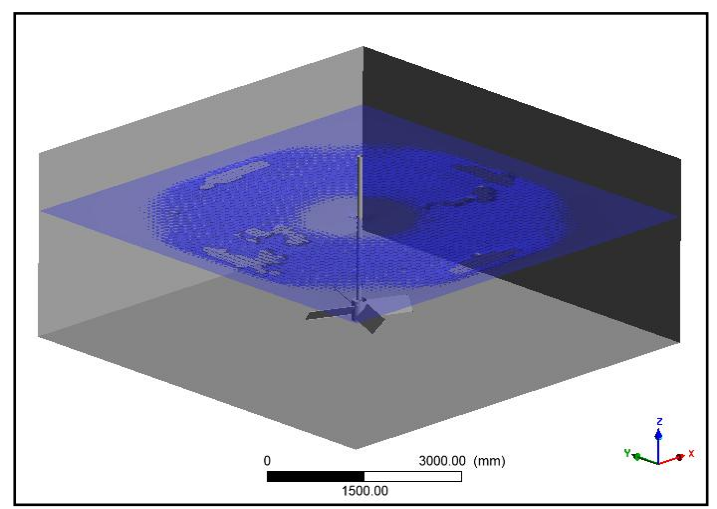

Gambar 3. Geometri simulasi sistem pengaduk kolam ekualisasi

\section{Simulasi Mesh}

Meshing merupakan tahap pencacahan domain menjadi subdomain yang lebih kecil yang dinamakan sel. Setiap sel akan diisi dengan variabel mekanika fludia seperti tekanan, kecepatan, turbulen, dan fraksi volume. Jumlah sel yang digunakan pada simulasi ini adalah 680.000 sel dengan tingkat kepadatan mesh di impeller lebih besar, seperti yang ditunjukkan pada Gambar 4.

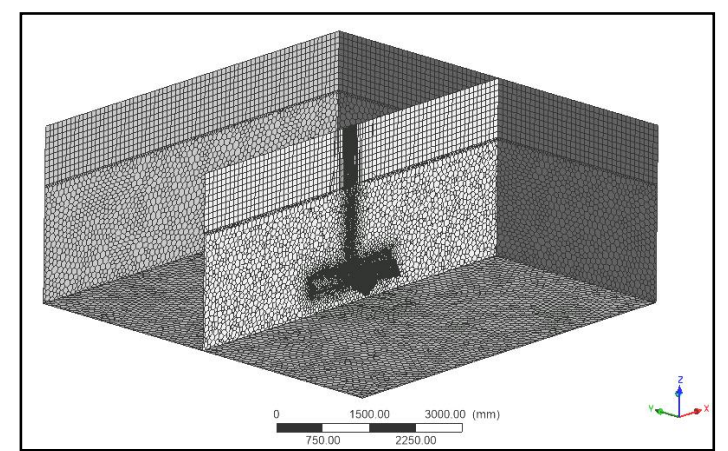

Gambar 4. Geometri simulasi mesh kolam ekualisasi

\section{Kontur Kecepatan}

Pengambilan data kontur kecepatan dilakukan pada 4 seksi plane yaitu, seksi $Y$ tengah, seksi $Y$ tepi, seksi $Z$ bawah, dan seksi $Z$ atas. Seksi $Y$ tengah berlokasi tepat ditengah, memotong pengaduk. Seksi $Y$ pinggir berlokasi diantara seksi $Y$ tengah dan dinding kolam. Seksi $Z$ bawah berada pada 0,25 meter di atas dasar kolam sedangkan seksi $Z$ atas berlokasi 2,40 meter diatas dasar kolam.

\section{Seksi Y}

Pengambilan data pada seksi $Y$ bertujuan untuk mengetahui resirkulasi arah aksial. Dari kontur kecepatan di atas didapatkan bahwa pada detik ke-1 aliran fluida mulai menuju ke bawah dengan kecepatan lebih dari $1 \mathrm{~m} / \mathrm{s}$ ditandai dengan kontur berwarna merah. Pada detik ke-2 fluida terdorong ke bawah dan menyebar ke arah samping. Pada detik ke-4 aliran fluida terus berkembang ke arah samping. Pada detik ke-6 limbah mulai menabrak dinding kolam dan menuju ke atas. Pada detik ke-8 dan ke-10, mulai terjadi resirkulasi aliran limbah dari atas menuju impeller terhisap ke arah bawah. Pada detik-detik berikutnya, resirkulasi akan terus berulang. Dari kontur di atas didapatkan bahwa kecepatan resirkulasi tersebar cukup merata pada seluruh kolam, hal ini menunjukkan bahwa performa pengadukan cukup baik, seperti ditunjukkan pada Gambar 5.

\section{Seksi Y Tepi}

Hal yang sama terjadi juga pada seksi $Y$ tepi. Dari kontur di atas didapatkan bahwa terjadi resirkulasi aliran pada seluruh plane, hanya saja pada kecepatan lebih rendah dari seksi $Y$ tengah. Hal ini terjadi karena seksi $Y$ tepi belokasi lebih jauh dari pusat impeller, seperti ditunjukkan oleh Gambar 6. 


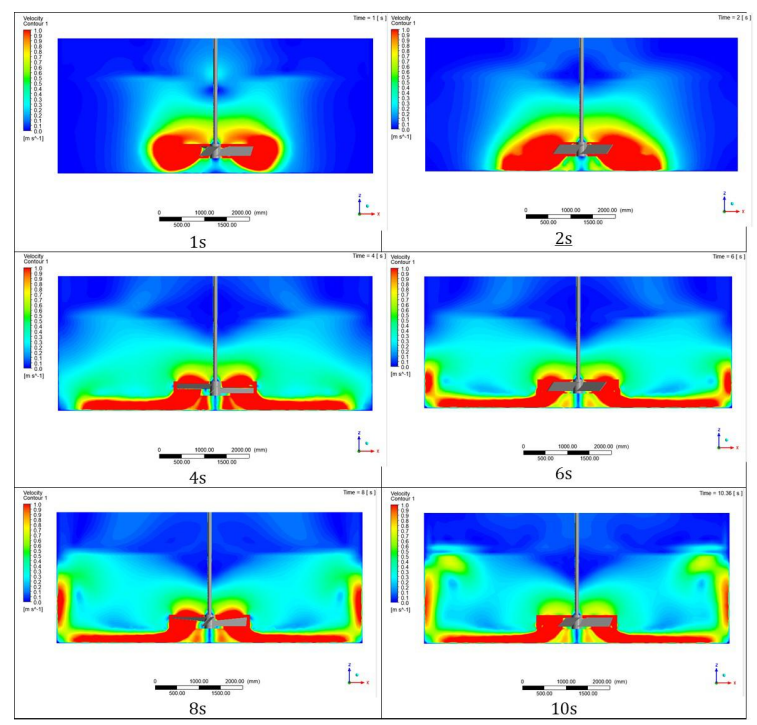

Gambar 5. Profil simulasi homogenitas fluida pada seksi $Y$

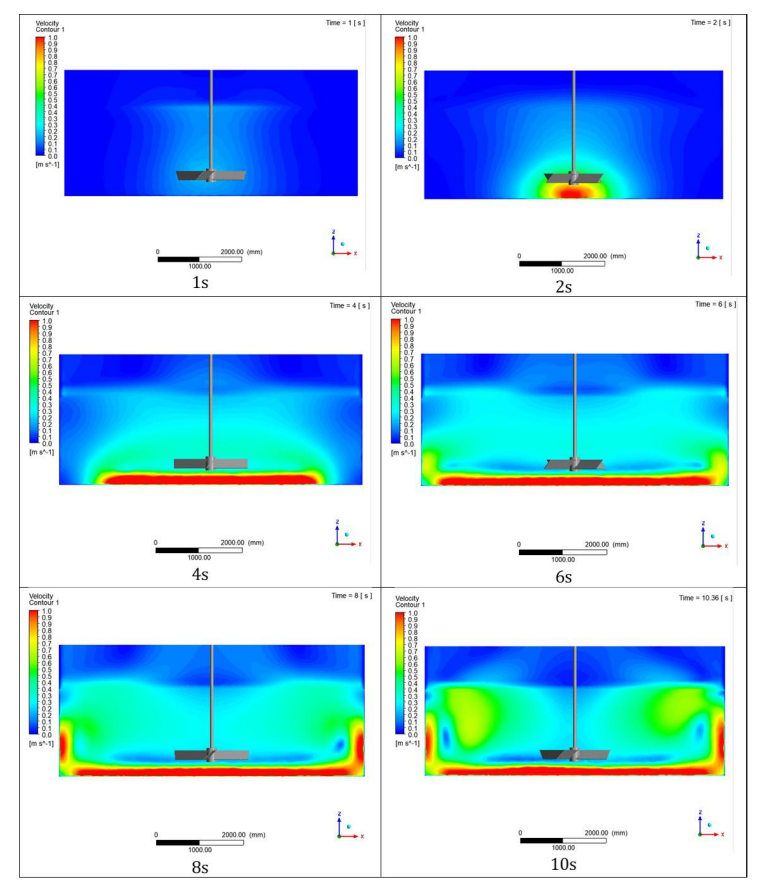

Gambar 6. Profil simulasi kecepatan fluida pada seksi $Y$ tepi

\section{Seksi Z Bawah (+0,25 m)}

Pengambilan data pada seksi $Z$ bertujuan untuk mengetahui distribusi kecepatan arah radial. Dari kontur di atas didapatkan bahwa seiring berjalannya waktu, kecepatan tersebar secara radial. Pada detik ke-10 dapat diamati bahwa seluruh plane hampir memiliki nilai kecepatan di atas nol. Hal ini menunjukkan bahwa terjadi resirkulasi pada lokasi tersebut. Simulasi ditunjukkan oleh Gambar 7.

\section{Seksi Z Atas (+2,40 m)}

Hal yang sama terjadi pada seksi $Z$ atas. Dari kontur di atas didapatkan bahwa terjadi penyebaran kecepatan arah radial pada seluruh plane, hanya saja pada kecepatan lebih rendah dari seksi Z bawah. Hal ini terjadi karena seksi Z atas belokasi lebih jauh dari impeller. Dapat diamati juga bahwa kecepatan ditengah sangat rendah (warna biru), hal ini tidak menunjukkan bahwa aliran tidak beresirkulasi, berdasarkan data vektor di bawah, tetap ada aliran ke arah bawah namun dengan kecepatan sangat rendah. Profil simulasi seksi $Z$ atas ditunjukkan oleh Gambar 8.

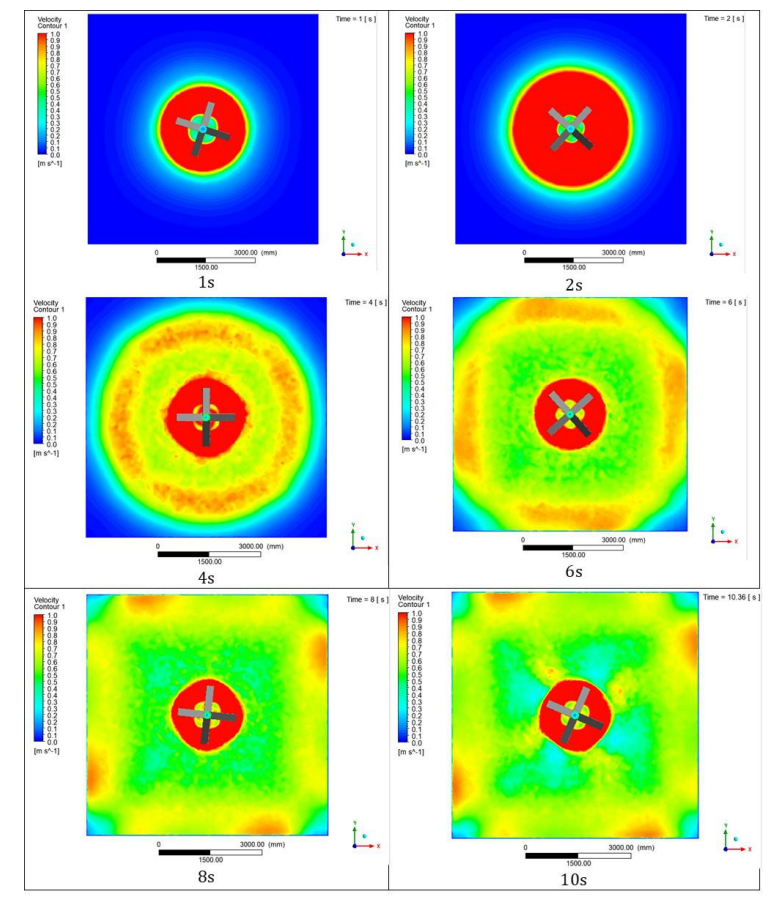

Gambar 7. Profil simulasi kecepatan fluida pada seksi Z

\section{Tampilan Secara Vektor}

Data vektor diatas menunjukkan arah resirkulasi kolam fluida. Dari vektor tersebut dapat diamati bahwa pada detik ke-10 aliran resirkulasi fluida terjadi hampir pada seluruh permukaan kolam dengan pola looping. Hal ini menunjukkan bahwa kinerja pengadukan cukup baik.

Pengambilan data iso-surfaces bertujuan untuk mengetahui keseragaman kecepatan aliran pada zona 3 dimensi. Dari kontur tersebut dapat diamati bahwa seiring dengan berjalannya waktu, zona yang memiliki kecepatan (non-zero velocity) akan semakin menyebar. Pada detik ke-10 hampir seluruh ruang kolam sudah memiliki nilai kecepatan lebih dari nol. Hal ini menunjukkan bahwa setiap partikel fluida bergerak dan beresirkulasi. Gambar 9 dan 10 berikut menunjukkan profil simulasi vektor pengaduk arah sirkulasi dan keseragaman. 


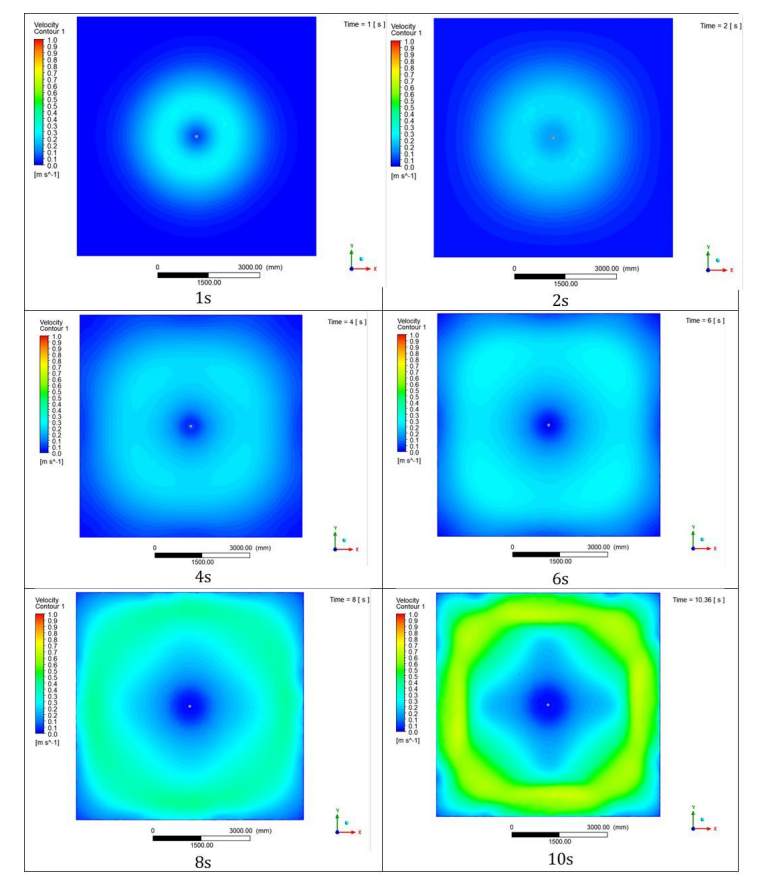

Gambar 8. Profil simulasi sebaran fluida pada seksi $Z$ atas

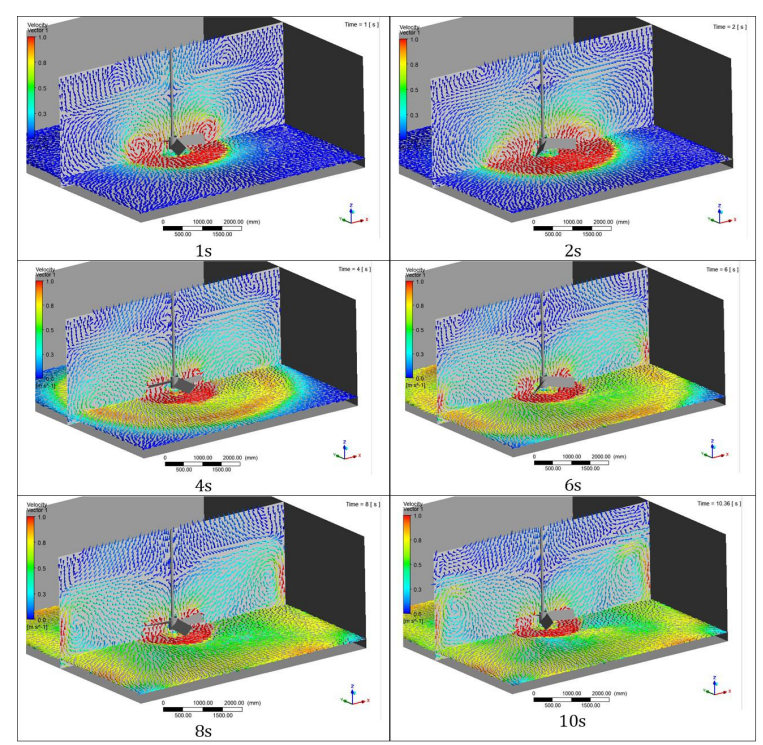

Gambar 9. Profil simulasi vektor pengaduk untuk arah sirkulasi

\subsection{Pengaruh Pengadukan}

Pada proses pretreatment biogas dari POME, sangat penting untuk menyiapkan kondisi ideal sebelum masuk ke reaktor biodigester. Parameter utama untuk keberhasilan proses produksi biogas antara lain adalah $\mathrm{pH}$, temperatur, dan homogenitas pencampuran substrat $^{(3)}$. Homogenitas substrat dapat dicapai dengan adanya sistem pengadukan atau agitasi pada proses pretreatment maupun pada reaktor biodigester.

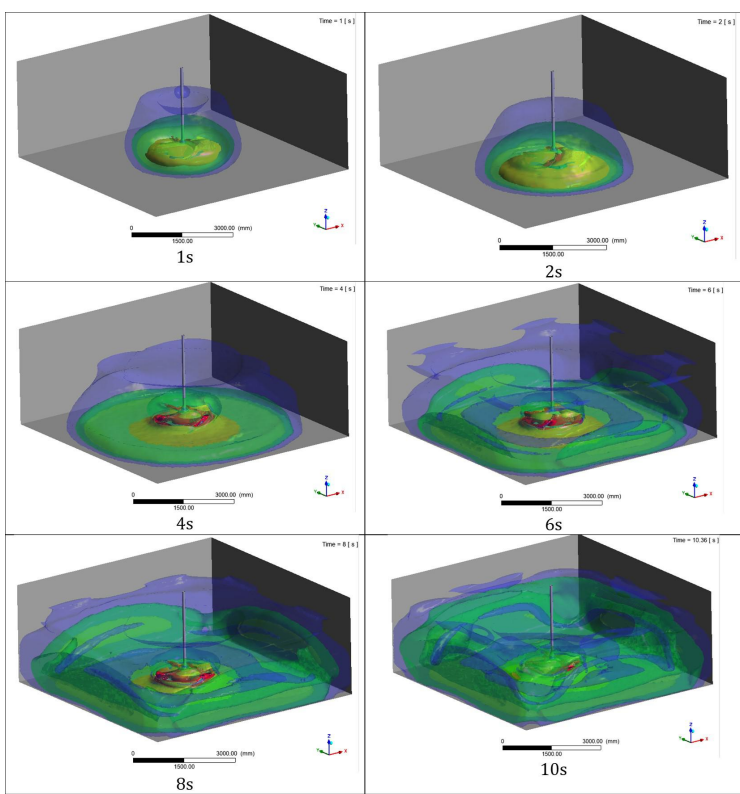

Gambar 10. Profil simulasi data iso-surfaces pengaduk untuk keseragaman

Pengaruh pengadukan terhadap pertumbuhan mikroorganisme cukup signifikan. Semakin tinggi laju pengadukan, maka kandungan volatile suspended solids (VSS) juga semakin meningkat. Hal ini mengindikasikan bahwa jumlah mikroba meningkat seiring dengan peningkatan laju pengadukan. Dalam penelitian sebelumnya disebutkan bahwa pada laju pengadukan $50 \mathrm{rpm}$ menunjukkan VSS sebesar 20.509,25 mg/L, dan mengalami peningkatan pada $150 \mathrm{rpm}$ menjadi $22.751,00 \mathrm{mg} / \mathrm{L}^{(12)}$.

Pada penelitan tersebut juga disebutkan adanya pengaruh pengadukan terhadap produksi biogas yang signifikan ${ }^{(12)}$. Saat pengadukan pada kecepatan $50 \mathrm{rpm}$ diperoleh rata-rata produksi biogas sebesar 52,46\%, dan mengalami peningkatan pada laju pengadukan 100 rpm dengan rata-rata produksi biogas sebesar $58,87 \%{ }^{(12)}$.

\section{KESIMPULAN}

Evaluasi terhadap perancangan pengaduk untuk kolam ekualisasi menyimpulkan bahwa desain pengaduk menggunakan tipe impeller pitch blade turbine dapat mencapai kondisi pencampuran fluida yang homogen dalam waktu yang cukup singkat, yaitu pada waktu di atas 10 detik telah tercapai homogenitas yang sangat baik pada arah aksial maupun radial. Berdasarkan hasil evaluasi perhitungan kebutuhan daya, maka daya yang dibutuhkan oleh pengaduk tersebut pada putaran $56 \mathrm{rpm}$ adalah sekitar $24 \mathrm{HP}$ atau $18 \mathrm{~kW}$. Pengaruh adanya pengadukan pada kolam ekualisasi juga sangat berpengaruh terhadap produktivitas biogas di dalam reaktor biodigester, dengan 
meningkatkan kondisi ideal $\mathrm{pH}$, temperatur, dan homogenitas pencampuran substrat.

\section{PERSANTUNAN}

Penulis menyampaikan terima kasih kepada Kemenristekdikti atas dukungan pembiayaan penelitian ini melalui Program Insentif Nasional tahun 2019. Penghargaan yang tinggi penulis sampaikan kepada PTSEIK BPPT dan PTPN V Riau yang telah mendukung terlaksananya penelitian ini.

\section{DAFTAR PUSTAKA}

1. Wahyudi, H., Kasry, A., \& Purwaningsih, I. S. (2011). Pemanfaatan limbah cair pabrik kelapa sawit untuk memenuhi kebutuhan unsur hara dalam budidaya tanaman jagung (Zea mays L.). Jurnal IImu Lingkungan, 5(2), 94-102.

2. Budianta, D. (2004). Pengaruh pemberian limbah cair pabrik kelapa sawit untuk pupuk cair terhadap kualitas air. Jurnal Pengelolaan Lingkungan dan SDA, 2(3), 147-154.

3. Hartley, C. (2004). Environmental impact of oil palm plantations in Malaysia. Palm Oil Research Institute of Malaysia (PORIM). Occasional Paper, 33, 1-27.

4. Roslan, A. M., Hassan, M. A., Aziz, S. A., \& Yee, P. L. (2009). Effect of palm oil mill effluent supplementation on cellulase production from rice straw by local funggal isolates. International Journal of Agriculture Research, 4, 185-192.

5. Wasewar, K. L. \& Sarathi, J. V. (2007). CFD modelling and simulation of jet mixed tanks. Engineering Applications of Computational Fluid Mechanics, 2(2), 155-171.

6. Thompson, J.S., et al. (2017). The use of CFD and multi-objective optimisation techniques to customise an industrial pre-mixer. Struct Multidisc Optim, 55(1), 2339-2351.

7. Rao, D.A., and Sivashanmugam, P. (2010). Experimental and CFD simulation studies on power consumption in mixing using energy saving turbine agitator. Journal of Industrial and Engineering Chemistry. 16(1), 157-161.

8. Yoshida, M. (2015). Liquid flow in impeller swept regions of baffled and unbaffled vessels with a turbine-type agitator. Brazilian Journal of Chemical Engineering, 32(4), 865-873.

9. Torotwa, I. \& C. Ji. (2018). A Study of the mixing performance of different impeller designs in stirred vessels using computational fluid dynamics. Designs, 2(10), 1-16.
10. Fathonah, N. N., Nurtono, T., Kusdianto, \& Winardi, S. (2018). Turbulent flow in a vessel agitated by side entering inclined blade turbine with different diameter using CFD simulation. International Conference on Mathematics: Pure, Applied and Computation, 974.

11. Chapple, D., Kresta, A., Wall \& Afacan. (2002) The Effect of Impeller and Tank Geometry on Power Number for a Pitched Blade Turbine. Trans Institution of Chemical Engineers, 80, 364-372.

12. Trisakti, B. (2016). Effect of Agitation on Methanogenesis Stage of Two-Stage Anaerobic Digestion of Palm Oil Mill Effluent (POME) into Biogas. International Seminar on Fundamental and Application of Chemical Engineering. 